\title{
The Schottenklöster in the World: Identity, Independence and Integration*
}

\author{
Diarmuid Ó Riain
}

\section{Introduction}

One of the central concerns of the original Enclaves of Learning, Religion, Ideology and Practice working group was to examine the multifaceted connections between the "enclave" and the surrounding world and to illustrate how texts produced within these communities served to both record and reinterpret this interaction as well as having the potential to change the underlying relationships. ${ }^{1}$ This approach essentially treats of the physical, legal or other factors underpinning the identification as an enclave of learning, religion, ideology and practice within the broader context of the institution's social relations, thereby seeking to redress the potentially problematic semantic implications of the term "enclave". The focus of my paper will be the so-called Schottenklöster or Irish Benedictine monasteries, which were established between the later 11th and early 13th centuries in modern-day southern Germany and Austria. That the monasteries of medieval Europe were deeply embedded in the wider social environment rather than detached islands goes, of course, almost without saying. ${ }^{2}$ This reality coexisted, however, with what Hallinger called the traditional gegenweltliche instincts of monasticism, and the rhetoric of withdrawal from the world would always remain prominent, particularly in the context of the emergence of new monastic movements. ${ }^{3}$ What makes the Schottenklöster an especially interesting case-study with regard to the interplay between idealized detachment and actual integration is the issue of ethnicity; the Irish identity of the monasteries was their sine qua non, and, accordingly, had a profound influence on the level of independence and integration they

* The research for this article was funded by the Austrian Science Fund (FWF): F42 Visions of Community.

1 See the introduction to this section.

2 See, for example, the contributions by Rutger Kramer and Christina Lutter to this volume as well as Melville, Welt der mittelalterlichen Klöster, 303-07, Vanderputten, "Introduction", and Lutter, "Geistliche Gemeinschaften".

3 Hallinger, "Zur geistigen Welt", 437. On the importance of the idea of Weltflucht within monasticism see Melville, Welt der mittelalterlichen Klöster, 13-18, 56, 114-15, 127-31, 167-68.

(C) DIARMUID Ó RIAIN, 2016 | DOI 10.1163/9789004315693_018

This is an open access chapter distributed under the terms of the Creative Commons Attribution-

Noncommercial-NoDerivatives 3.o Unported (CC-BY-NC-ND 3.o) License. 
sought and achieved. Texts written at the Schottenklöster reveal the concerns of the Irish monasteries in these matters, while promoting a particular concept of Irishness that, it will be argued, served simultaneously to emphasize the essential difference of the Irish monks and to communicate a sense of their belonging. Moreover, an examination of the historical record concerning the motivations of the early patrons of the Schottenklöster can help to cast light on the external reception of the Irish monks' visions of community. In short, this article will focus on the construction and safeguarding of the monastic identity of the Schottenklöster, and on the impact it had on the relationship between the monasteries and the outside world.

The ten Irish Benedictine monasteries-eight abbeys and two priorieswere part of a definable group or union, with the monastery of St James in Regensburg as motherhouse. ${ }^{4}$ The term Schottenklöster derives from the common Latin nomenclature for the monasteries, namely monasteria Scotorum, Scoti being the standard Latin word for Irishmen up to the high medieval period, at which point Hibernia began to replace Scotia as the chief designation for the island of Ireland. ${ }^{5}$ The origins of the movement can be traced back to a community of Irish monks that formed in Regensburg in the 1070s and which was attached to the extramural church of Weih Sankt Peter. Reportedly due to the great expansion in the size of the community, a second Irish monastery dedicated to St James was founded at Regensburg circa 1100 and would assume a central role in the movement's subsequent expansion, which began with the founding of a daughter-house in Würzburg around 1138.6 The Schottenklöster operated as a separate group within the Benedictine order, a situation given papal sanction in 1185 and again in the wake of the 1215 Laternan council, despite rules introduced there concerning the holding of general chapters and the conducting of visitations on a provincial basis. ${ }^{7}$

4 On the general history of the Irish Benedictine monasteries in Germany, see Hammermayer, "Die irischen Benediktiner-'Schottenklöster”; Flachenecker, Schottenklöster; Ó Riain-Raedel, "Irish Benedictine Monasteries"; Ó Riain, “Schottenklöster”; Weber, Iren auf dem Kontinent.

5 See Hammermayer, "Die irischen Benediktiner-'Schottenklöster”, 319-25; Richter, "Die Iren", 245 .

6 Although the establishment of the Schottenklöster at Erfurt is traditionally dated to 1136, I have argued elsewhere that the historical basis for this date is weak and that the monastery is not likely to have been founded until the 1150s; Ó Riain, "Schottenklöster", 237-79.

7 García y García, ed., Constitutiones concilii quarti Lateranensis, pp. 6o-62. The implementation of this canon XII, which was inspired by the Cistercian model, would ultimately prove very limited within the Benedictine order; see Flachenecker, Schottenklöster, 291-92; Cygler, Generalkapitel, 10-11; Moore, Pope Innocent III, 242, 270-71. Regarding the 1185 and 1215 papal bulls for St James, see below, n. 58 \& 59 . 
Instead the Regensburg monastery held rights of visitation and correction over the other Irish monasteries, the abbots of which were supposed to attend an annual general chapter at Regensburg. ${ }^{8}$ In reality, the leading role of the Regensburg motherhouse within the movement was the subject of repeated resistance during the more than 400 years of the monasteries' existence, and the integrity and distinct identity of the Schottenklöster group within the "fractured monastic landscape" remained more a matter of ethnicity than the product of any robust centralized power structure. ${ }^{9}$ These monasteries were Irish in more than just name: the national exclusivity of the brethren was jealously guarded. Only a few examples of this rule being circumvented are recorded, in some cases extremely ostentatious donations having led to particular local patrons being admitted to the community. ${ }^{10}$ The sources surviving from the medieval Schottenklöster speak only of the island of Ireland as the origin of their brethren. It is nonetheless conceivable that monks drawn from Gaelic-speaking parts of Scotland, the inhabitants of which could also be referred to as Scoti in the early and high medieval periods, may have entered the Irish monasteries. This seems more likely to have occurred in the earliest phase of the movement, when most of the monks, including Marianus and his initial companions, appear to have been natives of the northern part of Ireland, which had extensive cultural ties to Scotland. ${ }^{11}$ In the early 12th century, however, the principal source of Schottenklöster

8 See Hammermayer, "Die irischen Benediktiner-'Schottenklöster", 270-96; Flachenecker, Schottenklöster, 289-309.

9 Quotation from Vanderputten, "Introduction", xxıv. See also Röhrkasten, "Regionalism and Locality", 253-58.

10 One early German patron of the Irish monastery at Würzburg, called Adalhard, who contributed generously to the construction of the western end of the monastic church, was granted this honour before his death, according to an 1176 charter; Staatsarchiv Würzburg, Standbuch 545 (=Schottenklöster chartulary), fol. 8r; Wieland, "Schottenklöster", reg. no. 18; Oswald, "Westbau", 35-36. This is almost certainly the Adalhardus monachus Sancte Jacobi Wirceburgensis commemorated in both the Würzburg and general Schottenklöster necrologies on 28 and 29 January respectively; Ó Riain-Raedel, "Nekrolog", 53, 58. Another example appears to have been one Bethselinus, a townsman (urbanus) who is said in the Vita Mariani to have been the principal financier of the claustrum et claustri edificia erected at Weih Sankt Peter after the church was granted to Marianus and his companions; Weber, Iren auf dem Kontinent, 122-23. The Bezilinus monachus nostrae congregationis commemorated on 21 July in the Schottenklöster necrology is most probably the same individual; Ó Riain-Raedel, "Nekrolog”, 69; Flachenecker, Schottenklöster, 98-99; Weber, Iren auf dem Kontinent, 376.

11 See Broun, Irish Identity, 1-10 et passim; Woolf, Pictland to Alba, 312-50. 
monks switched to the southern province of Munster. ${ }^{12}$ It was there that a number of priories subject to the Regensburg Schottenklöster were established to serve the role of recruitment centres, in the hope of ensuring the supply of Irish novices necessary to sustain the monasteries on the Continent. ${ }^{13}$ Persistent difficulties in attracting sufficient personnel for all of the daughter-houses would, nonetheless, remain one of the chief problems that faced the Schottenklöster, the wave of expansion in the 12th century ultimately leaving the movement overstretched. ${ }^{14}$

\section{The Schottenklöster and Community}

As in the case of the enclaves which form the subject of Eirik Hovden's contribution to this volume, it is possible to discern different overlapping levels of community from an examination of the historical record concerning the Schottenklöster, and this approach can aid the contextualization and interpretation of the monasteries' literary output. A perception that each Irish monk belonged both to their respective individual monastic community and also to the larger group composed of the brethren of all of the Schottenklöster can be retrieved from surviving sources. For example, in addition to necrologies maintained at the individual monasteries, from the mid-12th-century onwards a necrology was kept at the Regensburg motherhouse recording the deaths of monks from all the Irish monasteries combined. ${ }^{15}$ It should be noted, however,

12 According to the Vita Mariani, the first abbot of the newly established monastery of St James at Regensburg was from the south of Ireland, his predeccessors at Weih Sankt Peter having hailed from the north; Weber, Iren auf dem Kontinent, 126. The subsequent Munster predominance within the Schottenklöster would persist into the 16th century and is clearly reflected in the sources surviving from the monasteries; see Ó Riain-Raedel, "Irish Kings and Bishops”; ead., "Cashel and Germany”; Flachenecker, Schottenklöster, 277-87; Ó Riain, "New Light".

13 Regarding the Irish priories, see Coombes, "Benedictine Priory"; Ó Riain-Raedel, "Nekrolog", 21-27; ead., "Irish Benedictine Monasteries", 58-63; Flachenecker, Schottenklöster, 282-87; Ó Riain, "New Light”; Weber, Iren auf dem Kontinent, 485-92.

14 Concerning the personnel difficulties experienced by the Schottenklöster, see Hammermayer, “Die irischen Benediktiner-'Schottenklöster”, 307-10.

15 This necrology is transmitted in a 17th-century copy: Vat. lat. 10100 (edited in Ó Riain-Raedel, "Nekrolog"). According to the transcript, the original necrology was kept from 1150 onwards. No medieval witness of a necrology survives from any of the individual Schottenklöster, but post-medieval necrologies ostensibly copied from earlier templates survive from the Irish monasteries at Regensburg, Würzburg and Vienna. On the community-building nature of 
that it was in the interests of the Regensburg motherhouse to foster an image of a "super-community" embracing all of the Schottenklöster, united by their ties to the motherhouse. ${ }^{16}$ The feeling of belonging may have been considerably weaker in the daughter-houses, which have generally left a much smaller mark on the historical record.

The Schottenklöster were urban monasteries, and plenty of evidence for a sense that the individual houses were part of their local civic communities is also available, and most clearly manifest in their participation in the annual rituals of feast-day celebrations and processions. A dramatic memorial testifying to the importance of such communal activities for the Irish monks can be seen to this day in Würzburg. Here in the late $13^{\text {th }}$ century the monks of the Schottenklöster strenuously objected to plans of the Teutonic Order to build their new church blocking the traditional route of processions to and from the Irish monastery. ${ }^{17}$ The Teutonic Knights were eventually forced to relent, and to incorporate a large passageway running under their church for the benefit of the Irish monks. While sources such as necrologies and deeds of donation also testify to interaction with civic elites, the extent to which the existence of the Schottenklöster impacted upon lower social groups within each town is difficult to determine. A limited caritative role can be inferred from isolated references to hospitals or pilgrim hospices, but the general paucity of evidence for pastoral engagement on the Irish monks' part suggests that, unlike the later mendicant orders, this was not a primary motivation for locating their houses at centres of population. As far as the texts produced at the Schottenklöster were concerned, it was the Irish monks themselves who were the pauperes christi deserving of charity, in keeping with a motif common within contemporary monasticism. ${ }^{18}$

memoria such as necrologies, see Schmid and Wollasch, "Gemeinschaft der Lebenden", 365-66; Oexle, "Memoria als Kultur", 37-41.

16 Quotation from steven Vanderputten's response to this section.

17 See Herzig, "Die Deutschordenskommende", 59-65. A letter written in 1290 to King Rudolf I by the abbots of the Benedictine monasteries of St Stephan and St Burkhard and the deans and chapters of the secular canonries of Neumünster and Stift Haug in Würzburg highlighted the importance of the relevant road to the Schottenklöster monks and its use as a processional route since time immemorial: “...quod quidam transitus, apud domum honorabilium virorum, fratrum Teutonicorum, extra muros Civitatis Herbipolensis, omnibus transeuntibus, prcecipue autem venerabilibus viris, Abbatj et conventuj Sancti Jacobi Scotorum, et etiam nobis in solemnibus processionibus nostris est communis et fuit, ante tempora quorum non extat memoria".; Würzburg, Staatsarchiv, Standbuch 545, fol. 2or; Bendel, ed., Urkundenbuch, vol. 1, no. 314.

18 On this concept, see Werner, Pauperes Christi,19-24, 198-99; Constable, Monastic Tithes, 169-70. The term is applied to the Irish monks three times in the Vita Mariani; Weber, Iren auf dem Kontinent, 92-95, 136-37, 160-61; see also the quotation in $n .36$ below. 
A sense that the Irish monasteries also saw themselves as part of a wider monastic community, not exclusively of Benedictine hue, can be read from their involvement in confraternities with non-Irish houses and from the travel of manuscripts between the Schottenklöster and outside monasteries. ${ }^{19}$ The prominent place of the Irish monastery at Vienna within the complex manuscript tradition of the 12th- and 13th-century Austrian annals provides a good illustration of the underlying contacts that existed between the Schottenklöster and other monasteries in the region belonging to various orders. ${ }^{20}$ The dissemination across southern Germany and Austria of hagiographical works and other Irish Kulturgut written or collected at the Regensburg Schottenklöster in the 12th century offers a further example. ${ }^{21}$

\section{Solos Elegimus Scotos: The Monastic Identity of the Schottenklöster}

There is nothing in the available sources to suggest that the form of communal life pursued in the Schottenklöster differed greatly from other Benedictine houses in the region, no indication of a particular reform agenda. What marked the Schottenklöster out from contemporary monasteries was primarily the ethnic make-up of their communities. The concept upon which the entire notion of a separate union of monasteries rested was the Irish identity of these Schottenklöster. Key to attracting the patronage necessary for the expansion and financial stability of the movement was therefore the ability to ensure that Irishness was not perceived as simply equating to foreignness, but instead carried with it notions of piety and monastic rigour. The Schottenklöster were greatly aided in this regard by the positive legacy attached to the Irish and pseudo-Irish missionaries and monastic pioneers who had made their mark on the Continent in the early medieval period. This had led within the ecclesiastical sphere to the intermingling of the concept of Irishness with notions of sanctity, piety and asceticism, a development most patent within the field of hagiography, where the spurious attribution of Irish origins to saints had been widespread for centuries before the emergence of the Schottenklöster. ${ }^{22}$

19 Wollasch, "Spuren Hirsauer Verbrüderungen”, 473-75; Ó Riain-Raedel, "Patrician documents", 713 n. 4.

20 See below, n. 79.

21 See Bieler, Four Latin Lives, pp. 233-34; Ó Riain-Raedel, “Patrician Documents”; ead., “Vita sancti Coemgeni", 147-52; Weber, Iren auf dem Kontinent, 697-749.

22 See Rutger Kramer's contribution to this volume for an example of this topos in Notker's 9th-century Gesta Karoli. The most detailed discussion of the Hibernicization phenomenon remains Koch, Sankt Fridolin, 55-92. See also O'Hara, "Constructing a Saint", 113-16. 
Indeed, at the very cradle of the Schottenklöster movement, Regensburg, a Life written in the mid-11th century had hibernicized a venerated late- 7 th- $/$ early-8th-century bishop of the town, Erhard, who in all likelihood actually hailed from the Narbonne region in southern France. ${ }^{23}$

There can be little doubt that the traditionally positive connotations attached to Irishness in an ecclesiastical context contributed towards the expansion of the Schottenklöster. This is clear in the case of the earliest daughter-house at Würzburg, founded by Bishop Embricho (ep. 1127-1146), where the memory of the Irish saint, Kilian, who is believed to have been martyred in the town in 689, is recalled in an 1142 confirmation charter. ${ }^{24}$ Although direct evidence is lacking, it is plausible that the local traditions of Irish saints also helped pave the way for the establishment of other daughter-houses such as those at Constance and Vienna. ${ }^{25}$ While the pre-existing goodwill would have made southern Germany and Austria a fertile ground for the Irish monks, in order to attract patronage on an ongoing basis it was incumbent upon them to ensure by word and deed that the outside perception of the all-important Irish identity of the Schottenklöster continued to be benign. The Vita Mariani, the key historical text produced at the Regensburg Schottenklöster in the 12th century, suggests that it was primarily the most favourable reputation of the Regensburg motherhouse that had moved Bishop Embricho to found a daughter-house at Würzburg. ${ }^{26}$ An 1161 confirmation charter issued by Duke Heinrich II of Austria in favour of the Schottenklöster he had founded at Vienna in 1155 provides less tendentious evidence for the Irish monasteries enjoying a strong standing at the time. The charter praises the simplicitas or pious innocence of the Irish monks and, in a remarkable endorsement of the mono-ethnicity of the Schottenklöster, suggests that the virtue of unanimitas, one of those central tenets of monastic life discussed in Christina Lutter's paper in this volume, was better nurtured within a community composed of monks belonging to a single gens:

Since it repeatedly comes to pass that no little diversity in character arises from the different customs of different peoples and out of the same

23 BHL 2590; Vita Erhardi, ed. Levison, p. 10; Koschwitz, "Der heilige Bischof"; Mai, "Der heilige Bischof"; Ó Riain, "Schottenklöster and the Legacy".

24 “...peregrini Scoti, videlicet compatriotae patronj nostrj, pretiosj martÿris Kiliani”; Würzburg, Staatsarchiv, Standbuch 545, fol. 1v; Wieland, "Schottenklöster", reg. no. 1.

25 See Ó Riain, "Schottenklöster and the Legacy".

26 BHL 5527; Weber, Iren auf dem Kontinent, 142-43. The memory of St Kilian is also cited as a motivating factor in the same passage. 
[develops] disagreement, we, wishing to prevent in every possible way the torments of envy and mutterings of discontent, which are thoroughly harmful to the unanimity of monastic life, in the disposition of this new plantation choose Irishmen only, of whose praiseworthy simplicity we know both from our own experience and above all through the reports of reliable witnesses ${ }^{27}$

Whether the Irish monks benefited elsewhere from similar perceptions of a correlation between ethnic diversity and discord is unattested. The Babelian tenor of this sentiment does find an echo in a passage early in the Vita Mariani. Here the author recounts that before reaching Regensburg, Marianus and his two Irish companions, Iohannes and Candidus, entered the Benedictine monastery of St Michael at Bamberg, ostensibly at the prompting of the illustrious Bishop Otto of the same town. ${ }^{28}$ Otto, having observed the zealous exertions of the three monks in respect of fraternal peace and charity and the fact that they were ignorant and inexperienced in the German language, decided to establish a separate cellula for the Irish monks at the foot of a hill neighbouring the Michelsberg. Here they are said to have been free to devote themselves to attending more diligently and more privately (accuratius ac secretius) to the precepts of divine law. This distinct Irish enclave is a proto-Schottenklöster, and the implication of the passage appears clear: a monastic life of superior quality is possible within a mono-linguistic or mono-ethnic environment. It seems thatjustification for the very existence of the ethnically exclusive Schottenklöster is being offered here. Furthermore, the author anachronistically proffers no less a figure than Bishop Otto of Bamberg, the foremost monastic patron of the high medieval period in the region, as a proponent of the concept of Irish-only monasteries.

Combined with a reputation for piety, during the phase of expansion such notions of a correlation between mono-ethnicity and accord may have led to a perception of the Schottenklöster as particularly well-equipped to rigorously fulfil the daily duties of the vita monastica. Such a semblance of a well-ordered

27 Hauswirth, ed., Urkunden, no. 4; also available at http://www.mom-ca.uni-koeln.de/ mom/AT-StiAScho/SchottenOSB/1161_IV_22.1/charter.

28 Weber, Iren auf dem Kontinent, 108-11. The involvement of Otto of Bamberg is a chronological impossibility, as Marianus and his companions would have to have been in Bamberg in the late 106os and Otto's episcopacy did not commence until 1102; Flachenecker, Schottenklöster, 6o-62; Weber, Iren auf dem Kontinent, 276-77. It seems likely that Otto was written into the story for reasons of prestige, the great monastic patron being cast here as an admirer and advocate of the Irish monks. 
claustral life would also have promoted the monasteries as eminently suitable guardians of the all-important memoria of potential patrons. A vital part of the memorial culture of any monastery was the necrology, and the Regensburg Schottenklöster appears to have maintained a list of deceased brethren and benefactors of it and its daughter-houses from at least the mid-12th century onwards. ${ }^{29}$

The benign opinion of the Irish monks held by Heinrich II of Austria, who would choose the Viennese Schottenklöster as his burial place, may have stemmed from direct contact with the Irish monastery at Regensburg, seat of the Duke of Bavaria, a position Heinrich II had held until his dispossession in $1154^{30}$ His sister Bertha, wife of the Regensburg Burgrave, Heinrich von Riedenburg, was a valued benefactor of the Regensburg Schottenklöster and had been interred within the chapter-house of that monastery circa $1150 .{ }^{31}$ She may have been one of those reliable witnesses referred to in the 1161 Viennese charter, among whose number may also have been Heinrich's half-brother and ally King Konrad III (reg. 1138-1152), who had himself founded a Schottenklöster at Nuremberg circa $1140 .{ }^{32}$ With regard to Konrad's own motivations for choosing Irish monks - who, according to the Vita Mariani, were charged with praying for the well-being of the imperium and its reges - it may again have been a case of personal experience combined with the recommendations of others. ${ }^{33}$ One of Konrad's closest advisors was namely Bishop Embricho, founder of the Würzburg Schottenklöster. ${ }^{34}$ The Staufer palace at Würzburg appears to have been located in close proximity to the Schottenklöster, and there is reason to believe that Konrad may have attended a consecration ceremony at the monastery in July $1138 .{ }^{35}$ Such royal endorsement of the monastic offering of the

29 Ó Riain-Raedel, "Nekrolog”, 49.

30 Whether Heinrich, then also Margrave of Austria, actually resided permanently in Regensburg or rather in Austria is uncertain; see Flachenecker, Schottenklöster, 215-16; Lechner, Babenberger, 245; Csendes, “Regensburg und Wien”. Heinrich's brother, Otto of Freising, refers to Regensburg as sedes ducatus in his Chronica sive Historia de duabus civitatibus, ed. Hofmeister, p. 349. Vita Mariani, § 15 (Weber, Iren auf dem Kontinent, pp. 138-39). Regarding Bertha, see ibid., pp. 497-99; Flachenecker, Schottenklöster, 101, 105. Indeed, he is credited in a 16th-century source with having commended the Irish monks to Heinrich II of Austria; Rasch, Stifftung und Prelaten.

33 Weber, Iren auf dem Kontinent, pp. 154-57.

34 Described by Konrad as "cor nostrum et anima nostra" in a letter sent to the Byzantine emperor, Manuel I in 1145; MGH, DD K III, no. 126; Otto of Freising, Gesta Friderici, ed. Waitz, p. 42. See also Ziegler, König Konrad III., 109-22.

See Ó Riain, "Schottenklöster", 121-23. 
Schottenklöster can only have boosted their attractiveness to potential patrons. Thus it appears that by the mid-12th century a reputation for a peculiar piety was bound up in the monastic identity of the Schottenklöster, which, while inextricable from the ethnic backdrop, supplemented the traditional positive connotations associated with Irish clerics on the Continent.

Written texts offered the Irish monasteries an additional means of enhancing their reputation, constituting a vehicle to explain and extol their unique monastic offering and to shape public perceptions of the essential Irish identity. To this end, the authors of the two principal historical texts produced at the Irish monastery in Regensburg in the 12th and 13th centuries, the Vita Mariani and the Libellus de fundacione ecclesie Consecrati Petri, fixed on a leitmotif characterizing the monks of the Schottenklöster as pilgrim monks or Scoti peregrini. This was part of an attempt to exploit and build upon the positive legacy associated with the Irish monastic and missionary tradition on the Continent in the early medieval period. Lacking a missionary purpose or pioneering form of monasticism, the notion of the Scoti peregrini provided a means to portray the monks of the Schottenklöster as successors of their venerated compatriots: they too had exiled themselves from Ireland to do Christ's work. ${ }^{36}$

Irishmen and the concept of the peregrinatio pro Christo, the author of the Libellus argued, were inextricably linked. ${ }^{37}$ The notion of the Irish Benedictine monks as Scotiperegrini was not an invention on the part of the author of the Vita Mariani, the idea already being well-rooted in the collective identity of the Schottenklöster. ${ }^{38}$ Earlier references to the Irish monks as monachi peregrini or Scoti peregrini in charters issued by Emperor Heinrich IV in 1089 and by Bishop Embricho in 1142 point to an external reception of this self-portrayal as pilgrim monks. ${ }^{39}$ The 1089 charter also refers to the monks of the Irish

$3^{6}$ The following sentence from the opening chapter of the Vita Mariani illustrates the author's strategy in this regard: "Quapropter antecessores nostri nos quoque Christi pauperes pro remedio animarum de finibus occidentis nudum Christum nudi sequentes, patriam carosque propinquos amore ac desiderio uitę cęlestis derelinquentes [...] commendabo". (I will commend to you why our predecessors and we also, the poor of Christ, following from a western land nude the nude Christ for the salvation of our souls, leaving behind our homeland and our dear relatives out of love and desire for a heavenly life); Weber, Iren auf dem Kontinent, pp. 92-94.

E.g. "Et duxerunt in consuetudinem omnes Scoti ab illo die invisere loca sancta Christi et peregrinari". (And they introduced the custom from that day forward for all Irishmen to visit sacred places and go on pilgrimage); Breatnach, Schottenlegende, p. 183.

38 For more on this subject, see Ó Riain, "Schottenklöster and the Legacy".

39 MGH, DD H IV, no. 403; Würzburg, Staatsarchiv, Standbuch 545, fol. 1v; Wieland, "Schottenklöster", reg. no. 1. 
monastery at Weih Sankt Peter, as "certain Irishmen, who had exiled themselves from their homeland for the torment of the body and the salvation of the soul, and who, after spending a long time visiting places of prayer, had come at last to Regensburg", a vision of the community which tallies closely with that offered in the Vita Mariani nearly a century later. Whereas the 1089 description can be said to reflect the fact that the Irish community at Weih Sankt Peter did in the early period include many Irish monks who had already been on the Continent - whether as pilgrims or, perhaps, resident in other non-Irish monasteries-before being drawn to Regensburg, by the time of the Vita Mariani's writing the Irish monasteries are likely to have been peopled predominantly with monks recruited directly from Ireland, who would have been much more firmly grounded in the Benedictine precept of stabilitas loci. While their self-portrayal as Scoti peregrini served to "other" the monks of the Schottenklöster, the extreme selflessness of pious exile differentiating them from all others, it can also be seen as an attempt at the normalization of the Schottenklöster; the authors of the Vita Mariani and Libellus contend that there were always Irish pilgrim monks active on the Continent and that the Schottenklöster were simply continuing this tradition. By association with their more illustrious compatriots, whose contribution to the development of the Church they highlighted-particularly with respect to southern German regions - a justification for the existence of their contemporary, exclusively Irish enclaves was being offered.

The image of the Schottenklöster monks as peregrini was further emphasized by the choice of the patron-saint of pilgrims, St James, for the motherhouse and three of the daughter-houses, while a further daughter-house at Eichstätt was dedicated to another pilgrimage cult, that of the Holy Cross and Holy Sepulchre. Although supporting the notion of the Irishmen as pilgrim monks, it is interesting that universal rather than Irish saints and cults were chosen. While there was a strong emphasis on Irish saints within the hagiographical and liturgical output of the Schottenklöster, they were never chosen for church dedications and very rarely for chapels or altars. ${ }^{40}$ This may be attributable to different target audiences for these media. The intended outside audience for hagiographical works produced at the Schottenklöster is likely to have been one located within a monastic milieu, while the dedications of churches, chapels and altars may have been chosen with an eye to the preferences of a more general public. The promotion of themselves as pilgrim monks and the fostering of pilgrimage-related cults may have contributed to the attractions of Irish monks for patrons during the 12th century, when 
interest in pilgrimage reached new heights in tandem with the Crusades. There is evidence, for example, that the cult of the Holy Sepulchre was strong at the Irish monastery at Weih Sankt Peter in Regensburg, and this association may well have been one of the principal considerations that led Walbrun, Dean of Eichstätt cathedral, to found a Schottenklöster dedicated to the Holy Cross and Holy Sepulchre at Eichstätt circa 1150. ${ }^{41}$

As an extension of the Irish monks' manner of self-representation there were a growing number of attempts to write the Regensburg Schottenklöster into the town's historical narrative by connecting the monastery or the notion of Scoti peregrini with celebrated figures and events in Regensburg's past. Building on the earlier Hibernicization of St Erhard, the Vita Albarti archiepiscopi was written at the Abbey of St James in the 12th century, possibly quite soon after the foundation of the monastery. ${ }^{42}$ The Vita sees Erhard, here cast as Bishop of Armagh, accompanied by Albart, Archbishop of Cashel, leaving Ireland for the Continent as peregrini pro Christo, both ending their days at Regensburg. The historically unattested figure of Albart was almost certainly invented by the hagiographer, the aims of the legend apparently being to fabricate a link between Ireland and Regensburg, to remind a local audience of the Irish origins of their venerated Erhard and to interpolate two Scoti peregrini into the historical tradition of Regensburg as forerunners of the Schottenklöster monks. This Life effectively amounts to an attempt to strengthen the position of the fledgling Irish monastery in Regensburg by integrating itself into local tradition.

The Libellus, a work part-history, part-fantasy, written anonymously at the Regensburg Schottenklöster in the mid-13th century, put it plainly when it depicted the monks of the Schottenklöster as arriving in Regensburg "post vestigia sanctorum Herhardi et Alberti" ("in the footsteps of Erhard and Albart").43 The Libellus shows due deference to the spurious cult of Albart and Erhard, but its greatest feat was to link the foundation of the Regensburg Schottenklöster in the 11th century directly to the most exalted of all German medieval figures, namely the long-deceased Charlemagne. He is said to have founded the church of St Peter at the site of his victory over a heathen enemy outside the walls of Regensburg, with Irish pilgrim monks arriving shortly afterwards to occupy

41 See Ó Riain, "Irish Jerusalem", 224-25.

42 BHL 218; Vita Albarti archiepiscopi Casellensis, ed. Levison. The legend is discussed at length in Hennig, "St Albert", 21-39; Flachenecker, "Hagiographische Werke", 110-13; Ó Riain-Raedel, "Cashel and Germany", 183-85; Weber, "Konstruktion”; id., Iren auf dem Kontinent, pp. 732-35; Ó Riain, "Schottenklöster and the Legacy”. 
the church, in accordance with an angelic vision experienced by the Emperor. ${ }^{44}$ Despite the extraordinary chronological gymnastics performed by the author of Libellus - Marianus, who lived a quarter of a millennium later, was among the first Irish monks to arrive-this so-called Regensburger Schottenlegende gained widespread acceptance within the Regensburg historical tradition, before being repudiated by Aventinus in the early 16 th century. ${ }^{45}$ As in the case of the Vita Albarti, the attempt to embed the Schottenklöster within the town's historical narrative is unmistakable.

It is difficult to determine the impact the Schottenklöster strategy of attaching themselves to the tradition of the saintly Irish monks and missionaries of the early medieval period had on the outside world, whether their particular vision of community was shared by an external audience. The content of the Libellus, which aside from its glorification of all things Irish includes praise and pseudo-historical material concerning Ratispona urbs preclara, leaves little doubt that the work was aimed in part at a Regensburg readership. ${ }^{46}$ The incorporation of the Charlemagne legend or Schottenlegende into the town's late-medieval and early modern historical narrative, albeit with the Irish element toned down, indicates success in this regard ${ }^{47} \mathrm{~A}$ Regensburg target audience can also be assumed for the Vita Albarti, but its reception was more limited, perhaps due in part to fundamental inconsistencies with the Vita Erhardi, which made no mention of the saint's peregrinatio or his purported companion, Albart. ${ }^{48}$ The development of a modest cult associated with Albart

44 Ibid., 158-234.

45 Aventinus, Herkommen der Stadt Regensburg, ed. Lexer, pp. 294-97: "Es stên in der lugent drauß zu Weich S. Petter noch wol mêr lugen, als das die Schotten zu kaiser Karls zeiten her kumen solten sein..." (296). See also Kraus, Das Bild Regensburgs, 86-102.

46 Breatnach, Schottenlegende, p. $15^{8}$ (quotation).

47 The Libellus is transmitted in whole or part in 16 manuscripts, all but two of which were copied from other, lost witnesses; Breatnach, Schottenlegende, pp. 79-112. The Latin text was also translated into German verse and prose versions in the 14th century; Shaw, Karl der Große; Gröber, "Res factae versus res fictae". On the reception of the Libellus see also Kraus, Das Bild Regensburgs, 90-102; Wolf, Bilder und Vorstellungen, 214-20.

48 The Vita Erhardi and Vita Albarti appear, nonetheless, as consecutive items in two manuscripts of Regensburg provenance, one an early-13th-century legendary from the Benedictine monastery of St Emmeram, the other a compilation from the Franciscan friary dating to between 1434 and 1436; 1) Munich, Bayerische Staatsbibliothek, Clm 14473: Halm et al, Catalogus codicum latinorum, vol. 4/2, 178; Klemm, Die romanischen Handschriften (text vol.), 43;2) Munich, Bayerische Staatsbibliothek, Cgm 2928: Schneider, Die deutschen Handschriften, 364-379. The complete Life is otherwise only preserved in the late-12thcentury, Magnum Legendarium Austriacum; Poncelet, "De Magno Legendario Austriaco", 62; Ó Riain, "Magnum Legendarium Austriacum”; id., "Schottenklöster and the Legacy". 
is, nonetheless, indicated by the construction of a sepulchral monument for the saint at the Niedermünster canonry in the 14th century.

The question of the intended audience of the Vita Mariani is a particularly interesting one. Ostensibly an account of the exploits of Muiredach Macc Robartaig, who is styled therein as the founding father of the Schottenklöster movement, the Life, written by an anonymous author at the monastery of St James in Regensburg circa 1180, is more a historia fundationis than a hagiographical work; the recounting of the role of Marianus in the foundation of the first Irish monastery of Weih Sankt Peter in Regensburg soon makes way for an outline of the history of the Schottenklöster movement up to the time of writing. ${ }^{49}$ This work was undoubtedly aimed in part at an internal audience, as the author's invocation of his fratres towards the beginning of the Life suggests, thereby seeking to shape the collective memory of the Regensburg community. ${ }^{50}$ Unsurprisingly, considering where it was written, the Vita Mariani narrative represents very much a Regensburg version of events, emphasizing the central role of the Abbey of St James in the founding of each daughter-house, and asserting its primary position within the movement. It seems likely that a wider "internal" audience, comprising the monks of the other Schottenklöster, who would arguably also have been understood as the author's fratres, was also intended to receive this message. Although none of the surviving text witnesses is associated with these daughter-houses, there is some evidence for the work's reception there. ${ }^{51}$ Flachenecker speculated that the Vita Mariani might have been laid before Pope Lucius III as evidence supporting Regensburg's

49 Marianus dies ten chapters into the work and after receiving a couple of mentions in passing $(\$ 11 \& 12)$ is the subject of a final reference in the concluding chapter 24. Only one miracle is attributed to Marianus in the Life ( $\S 8)$, and there is little evidence for his cult having been otherwise fostered at the medieval Schottenklöster in Regensburg (chapter numbers after the edition in Weber, Iren auf dem Kontinent).

5o Weber, Iren auf dem Kontinent, 102. The general message of Regensburg's primordial role and its importance to the cohesion of the Irish monasteries is delivered in symbolic terms in one particular passage in the Vita, where the author suggests that many of the Irish monasteries in Bavaria and Franconia rely for the most part upon manuscripts transcribed by Marianus himself, who was indeed a noted scribe; Weber, Iren auf dem Kontinent, pp. 114-15. This motif neatly ties all of the Schottenklöster to the Regensburg motherhouse through the person of the movement's founding father.

$5^{1} \quad$ For example, passages from the Vita Mariani provided the basis for a foundation history written at the Schottenklöster of St Aegidius at Nuremberg in the 14th or 15th century, and contained in "Das altt sal puch deß closters santt Egidii in Nuremberg"; Nuremberg, Stadtarchiv, A 21-2: No. 107, fols. 36r-39v (Extracts reproduced in Pfeiffer, "Anfänge der Egidienkirche", 261-62). For a discussion of the dating, see ibid., 262; Flachenecker, Schottenklöster, $183^{-84}$. 
claim to the leadership role within the Schottenklöster movement, a position recognized by the 1185 papal bull. ${ }^{2}$ That a perceived need for papal confirmation of Regensburg's status as the group's leader inspired the composition of the Vita at this particular point in time is certainly conceivable. The Life was written after the great expansion of the movement in the mid-12th century and contemporaneously with the completion of an elaborate new monastic complex at Regensburg, and the writing of a historia fundationis would be consistent with a prevailing desire to consolidate and take stock. It appears certain that the author intended his account of the great achievement of the Irish monks from their humble origins at Weih Sankt Peter to broadcast the virtues of the Schottenklöster to the wider world. The modest manuscript transmission of the Life, however, speaks against a particularly widespread reception for his work outside of the enclave. ${ }^{53}$ While the Libellus incorporated much material drawn from the Vita Mariani, its fantastic retelling of the foundation history of the Irish monastery at Regensburg easily eclipsed the considerably more sober account contained in the earlier work with regard to its impact on an external audience.

\section{"Hec Est Mea Plantacio": The Independence and Legal Status of the Schottenklöster}

Because the Irish identity of the Schottenklöster monks was the essential point of difference in their monastic package and underlay the whole concept of the Regensburg-led union of monasteries, it required not only promotion, but also protection. The earliest charter surviving from the Schottenklöster at Regensburg, arguably the most extraordinary document among a rich diplomatic collection covering the 450 years of the Irish presence in the town, was crucial in this regard. As mentioned above, in 1089 Heinrich IV granted imperial protection to a group of Irish monachi peregrini, who had for some time being pursuing a vita monastica at the church of Weih Sankt Peter in Regensburg. ${ }^{54}$ The securing of the mundiburdium defensionis of the Emperor, the highest secular power, was undoubtedly a major coup for the Irish monks, for this was a monastic community in a fledgling state and hitherto in a legal limbo. While, as foreigners, the Irishmen could as individuals expect to receive

\footnotetext{
$5^{2} \quad$ Flachenecker, Schottenklöster, 290.

53 The Life is preserved in ten manuscripts, the earliest five of which belong to exemplars of the Magnum Legendarium Austriacum; Weber, Iren auf dem Kontinent, pp. 27-6o.

54 MGH, DD H IV, no. 403.
} 
the level of protection traditionally afforded to pilgrims and monks in the high medieval period, the emergence of a permanent monastic community at Regensburg created a new and uncertain legal situation. ${ }^{55}$ The circumstances were complicated further by the fact, as stated in the 1089 charter, that the church of Weih Sankt Peter did not belong to Irish monks, and their use of it was dependent on the assent of the owner, the abbess of the Obermünster canonry, and of the Bishop of Regensburg. The hitherto ambivalent standing of the Irish community, which had by this stage occupied the Weih Sankt Peter site for more than a decade, is reflected particularly in the opening line of the charter, which colourfully describes the recipients as "quidam Scottigenae pro cruciando corpore salvandaque anima patria sua exulerant ac diu orationum loca visitantes Ratisponam tandem venerant". ${ }^{66}$ The granting of the imperial charter gave the Irish monastic community an independent legal status, notwithstanding the recognition of the rights of the Obermünster abbess in relation to the property, and marks a major step towards the integration of the enclave into the wider legal, ecclesiastical and social framework.

This was the first of numerous royal and papal privileges received by the various Schottenklöster, which, in addition to charters granted by the founders of the individual daughter-houses, bestowed a legal standing and a level of secular and ecclesiastical protection upon the Irish monasteries in medieval Germany and Austria that was basically equivalent to that enjoyed by a "local" Benedictine institution. Yet the monasteries' Irish identity-their sine qua non-did impinge to a certain degree upon their legal status and prompted a particular concern with the issue of independence. The Irish monasteries were marked out from other Benedictine houses by virtue of their affiliation to the wider Regensburg-led union. Because this union was basically built on materfilia relationships, analogies can be drawn with contemporary Cistercian practice, but the key ingredient of ethnicity makes the Schottenklöster group a unique phenomenon. The existence of this union of monasteries under the rule or regimen of the abbot of St James in Regensburg is attested in a papal bull of 1185, which also contains reference to an already existing practice of holding general chapters of Schottenklöster at the motherhouse. ${ }^{57}$ While reforms introduced at the 1215 Lateran council, which prescribed the holding

55 Thieme, "Fremdenrecht"; Schubert, "Fremde", 13-16. From the mid-11th century onwards a series of papal decrees calling for the protection of, among others, pilgrims and monks were also issued; Birch, Pilgrimage, 84-85.

$5^{6}$ For translation, see above, p. 394.

57 Ried, Codex chronologico-diplomaticus 1, no. 285;, Germania Pontificia 1.2, ed. Brackmann, p. 293. 
of regional general chapters within the Benedictine order with associated powers of visitation and correction, had the potential to impinge upon the integrity of the union of Schottenklöster, a charter obtained from Pope Innocent III by the Regensburg motherhouse excluded the Irish monasteries from the new arrangement. ${ }^{58}$ This ensured the independence of the group as a whole, but, by virtue of the powers granted to the Regensburg abbot by successive papal bulls, the autonomy of the daughter-houses in respect of matters such as the election of abbots could be constrained.

The unique Irish identity of the Schottenklöster gave rise to other noteworthy developments that would influence the level of their independence and integration. Lacking strong kinship or other ties to their new surroundings, the Irish monks were in a potentially vulnerable position, or at least this may have been the perception, both on their part and that of others. Arising from the outsider status of the Schottenklöster, a relatively pronounced dependence on their founders and protectors is appreciable, particularly in the foundation phase. ${ }^{59}$ This reliance probably explains one of the curious aspects of the Schottenklöster, namely that all houses were erected within urban areas, rather than in the relative isolation of the countryside, as was the dominant preference within contemporary monasticism. The need for physical proximity to their patrons' power centres, presumably for reasons of physical security and the safeguarding of their independence, most likely inspired this choice. In a number of cases, the Viennese house being a salient example, the monastery and residence of its patron were situated almost side-by-side. ${ }^{60}$

The unusual willingness of the Irish monks to establish monasteries in urban areas may have been one of the attractions of the movement to its

$5^{8}$ This bull does not survive, but its content is known from its citation in 13th- and 14th-century charters relating to the Regensburg, Erfurt and Vienna monasteries; Hammermayer, "Die irischen Benediktiner-'Schottenklöster", 272; Flachenecker, Schottenklöster, 293-94.

59 Cf. Hammermayer, "Die irischen Benediktiner-'Schottenklöster", 270: "Als Fremdlinge auf Wahrung nationaler Eigenständigkeit bedacht, blieben die Irenmönche in weit stärkeren Maße als die deutschen Konvente angewiesen auf die Unterstützung durch weltliche und geistliche Herrschaftsträger. Reichsrechtliche bzw. kanonische Fixierung und Konfirmation ihrer Rechte und Freiheiten, urkundliche Sicherung des jeweiligen Güterbestandes bedeuteten für die Iren Existenzfragen; sie konnten positiv nur beantwortet werden mit Hilfe des Kaisers, des Papstes und der jeweiligen Territorialherren".

6o The Schottenklöster at Vienna stood in close proximity to the believed site of the Babenberg palace, namely the square known today as Am Hof; Lechner, Babenberger, 245; Csendes, "Aufenthaltsorte der Babenberger", 29; id., "Regensburg und Wien”, 168; Ebner, "Frühgeschichte Wiens”, 63; Ó Riain, “Schottenklöster", 282-83. 
patrons during the 12th century. In a number of cases, including Nuremberg, Memmingen and Vienna, the monasteries were the first religious houses to be founded within a town at a stage early in its development. The construction of the Schottenklöster can be viewed in the context of the desire of the founder, in each case also the town lord, to develop the urban area, a monastery being a virtually indispensable part of any medieval town's infrastructure. The Irish monks could prove useful to their founders in other practical ways; there is evidence that the monks of at least two daughter-houses performed scribal duties in the chancelleries of their patrons, while there are some instances where members of the community appear to have also occupied the role of royal or ducal chaplain. ${ }^{61}$ The term court-monastery might not be too strong a term to describe the relationship between some houses and their founders and successors, albeit for limited periods. It may be that the vulnerability of the Irish monks arising from their outsider status resulted in them being more compliant to their benefactors' wishes in relation to the manner in which the monasteries functioned. A perception that this was the case may again have contributed to the attractiveness of the Irish monks to potential patrons in the 12th century. Perhaps the simplicitas spoken of in Heinrich II's 1161 confirmation charter for the Viennese Schottenklöster should, beyond its connotations of an exemplary piety, also be interpreted to encompass a perceived innocence on the part of the Irish monks in worldly affairs and thus their greater potential malleability from the founder's perspective. ${ }^{62}$

The Irish monasteries' need to have their independence safeguarded led to a growing dependence on their patrons. This could have dramatic consequences, as an example concerning the Viennese Schottenklöster illustrates. The relationship between the monastery, which had been founded by Duke Heinrich II in 1155, and the Babenberg court remained close into the 13th century, but a perception of the Schottenklöster as a Babenberg institution encouraged Duke Leopold vi to seek to evict the Irish monks in the early 13 th century in order to convert their monastic church into the cathedral of the planned new Viennese diocese. Through recourse to the papacy, thereby pitting one defensor against another, the Irish monks were able to stave off Leopold's attempts and the plan to erect a new diocese ultimately failed. ${ }^{63}$ Interestingly,

61 Flachenecker, Schottenklöster, 175-77, 180-90, 233-34

62 See above, p. 390-391.

63 The monastery had received papal privileges in 1177, 1185, and 1191. In response to Leopold vi's attempts to gain papal approval for his diocesan scheme, which was also strongly resisted by the Bishop of Passau, Abbot Marcus managed in 1208 to secure confirmation of the papal protection owing to the Schottenklöster, in effect helping to force Innocent 
the Viennese Schottenklöster had secured its first papal privilege within three months of the death of Heinrich II in 1177.64 Perhaps this initiative indicates an awareness on the part of the Irish monks that their dependence on the Babenberg dynasty had left them somewhat vulnerable and that the founder's successors might not remain as benignly disposed towards their monastery, notwithstanding that it is stated in the charter that it was the new duke, Leopold $v$, who requested papal protection for the monastery. The advantages of having a counterweight to Babenberg guardianship were certainly borne out during the diocesan affair.

A distinction must be drawn between the Schottenklöster daughter-houses and the Regensburg motherhouse with respect to their level of independence. As mentioned above, the rights attached to Regensburg's papal-sanctioned stewardship of the union of Schottenklöster circumscribed to a certain degree the autonomy of the daughter-houses. Furthermore, the Abbey of St James was in the unusual position of being a monastery effectively without a founder. While, according to an 1112 imperial charter, a large number of leading Regensburg citizens paid for the purchase of the site of the monastery, there was no single founding figure associated with the establishment. ${ }^{65}$ The issues affecting a monastery's autonomy attaching to the dependence or overdependence on a founder did not therefore arise in the case of St James. This is not to suggest that the question of its level of independence was not a concern for the motherhouse. The circumstances surrounding the emergence of the Irish monastic community at Weih Sankt Peter must surely have fed anxieties in this regard. As discussed above, the Irish monks had the use but not ownership of the church of Weih Sankt Peter, which belonged to the Obermünster canonry, whose abbess could claim significant rights with respect to the running of the Irish monastery there. ${ }^{66}$ According to an episcopal decision of 1216, these included the right to choose the prior of Weih Sankt Peter from among its brethren and that of St James, a power retained until at least the middle of the 15th century. ${ }^{67}$ The issue of independence is broached a number of times in

III's hand in the matter; Hauswirth, ed., Urkunden, nos. 6, 8,10, 13; Germania Pontificia 1.1, ed. Brackmann, pp. 252-53; also available at http://www.mom-ca.uni-koeln.de/mom/ AT-StiAScho/SchottenOSB/fond?block=1. Regarding Leopold vi's endeavours in this respect, see Lechner, Babenberger, 200-03; Flachenecker, Schottenklöster, 227-28; Krabbo, "Versuche der Babenberger", 17-24.

64 See preceding note for references.

65 MGH, DD H V, no. 100.

66 See Flachenecker, Schottenklöster, 98.

67 "Quando Prioratus sancti Petri vacabit Priore, abbatissa superioris Monasterii veniens ad abbatem et Conventum sancti Jacobi et Deum pre oculis habens petat aliquem Scotum de 
texts produced at the Regensburg Schottenklöster. For the most part, this involved the authors trumpeting the autonomy of the monastery. A salient example is provided by the Vita Mariani, the late-12th-century hagiographical work cum foundation history already encountered above. After describing the origins and development of the Schottenklöster movement up to the time of writing, the narrative reaches something of a crescendo with the following statement, which appears in the Life's penultimate chapter:

Indeed, what I find otherwise more worthy of admiration is that, so far from home, with only the help of God and without the support of any worldly prince or bishop, the saintly men and simple pilgrims from the land of Ireland providently and fittingly erected a church in honour of God and St James in a suburb of Regensburg. And with the help of the living God, with the advice and assistance of Pope Calixtus and the pious Emperor Henry the elder, made it in such a way independent, that neither the emperor, nor the Bishop of Regensburg, nor the Duke of Bavaria, nor the Burgrave of that town, nor any man other than the Irish can truthfully say: "This is my plantation, this is my institution, by the law of inheritance I can hold possession of this house of God, this sanctuary". ${ }^{\prime} 8$

Here only the reference to the assistance of pope and emperor tempers the absolutism of the author's declaration of independence and his picture of single-handed achievement on the part of the Irish monks. ${ }^{69}$ The importance of imperial and papal protection to the founderless Irish monastery alluded to here is more strongly emphasized elsewhere in the Life. ${ }^{70}$ According to the author of the Vita, a privilege granted to the abbey by Innocent II, while confirming the papacy's cura et tutitio of the Irish monastery, stated that the

ipso Conventu vel de Fratribus sancti Petri idoneum sibi dari Priorem, et si bonus ac idoneus est, quem postulaverit, dandus erit in Priorem Ecclesie prenominate"; Ried, Codex chronologico-diplomaticus, no. 335 .

68 Weber, Iren auf dem Kontinent, pp. 162-64.

69 The author is mistaken here in his reference to Henry the Elder; it was Heinrich v rather than his father who was a contemporary of Pope Calixtus and who granted the new monastery of St James an imperial privilege in 1112.

Reference is also made to the various imperial and papal charters underpinning the libertas of the monastery at $\$ 9$ (1089 imperial charter), \$12 (1112 imperial charter and the privilege received from Pope Calixtus), §14 (charter granted by Innocent II) and §23 (list of all papal privileges received to date: Calixtus (date unknown), Innocent II (date unknown), Eugene III (1148), Adrian IV (1156) and Alexander III (1177)); Weber, Iren auf dem Kontinent, pp. 122-23, 130-31, 134-35, 164-65. 
emperor was to serve the role of its lay advocate and protect it from an unjust attack, insofar as the monastery concerned both the curia Romana et dominus imperator. ${ }^{71}$ This is a somewhat curious mingling of papal and royal protection and particularly interesting on account of the implication that it was the duty of the emperor to enforce not only his own but also the pope's responsibilities with respect to the Schottenklöster. Because no privilege from Innocent II actually survives, it must remain open as to whether the content of the charter, presuming it existed, is accurately recounted in the Vita Mariani. The passage appears to reflect notions of the emperor as advocatus of the Roman church as they were current in the second half of the 12 th century. ${ }^{72}$ Instances of the role of emperor as advocate of individual papal-protected monasteries being said to derive from his position as advocatus Romanae ecclesiae arise in this period and the contemporary development of the concept of the emperor as defensor of all Cistercian houses within the empire can also be seen to be rooted in the same underlying idea. ${ }^{73}$

As is most clear in respect of the 1089 charter, the privileges received from pope and emperor were, in effect, as Hammermayer put it, Existenzfragen for the Irish monks, protections without which the enclave could not hope to prosper. ${ }^{74}$ With regard to imperial protection, the question arises as to what figure was actually entrusted with the protective role of the emperor on the ground in Regensburg by serving as the monastery's advocatus. There is no clear documentary evidence to illuminate this issue, but there are certainly hints that the Regensburg Burgraves, a position held by members of the Babonen or von Riedenburg family from 974 until the late 12th century, occupied this role. ${ }^{75}$ This would make the mention of the Burgrave in the above excerpt from the Vita Mariani more pointed.

The recorded circumstances of the foundation of St James cast further light on the context of the reference to the Burgrave in the above quotation from the Vita Mariani. The imperial privilege granted by Heinrich V in 1112 credits Burgrave Otto von Riedenburg and 16 named Regensburg citizens with the purchase of the site for the monastery. ${ }^{76}$ This charter was clearly available as a source for the author of the Vita, but his account of the acquisition of the site

\footnotetext{
71 Weber, Iren auf dem Kontinent, pp. 134-35.

72 See Goez, "Imperator advocatus Romanae ecclesiae"; Schuldi, “Advocatus sanctae Romanae ecclesiae", 41-47.

73 See Hirsch, Klosterimmunität, 108-22; Szabó-Bechstein, “Libertas ecclesiae”, 164-72.

74 See quotation in n. 6 o.

75 Störmer, "Babonen”; Flachenecker, Schottenklöster, 265-66.

76 MGH, DD H V, no. 100.
} 
transforms Otto into a mere mediator between the Irish monks and the vendor. While unnamed Regensburg citizens are said to have contributed generously towards the payment of the masons who built the monastery, in the light of the 1112 charter the Vita account essentially amounts to an underplaying of outside involvement in the foundation process. This approach almost certainly stems from the author's desire to stress the independence of the Regensburg monastery, leading ultimately to the sentiments expressed in the bombastic statement quoted above. The 16 Regensburg cives involved in purchasing the site were effectively written out of the monastery's foundation history, and the role of the leader of the group and therefore the nearest thing the Schottenklöster had to a potential founding figure, Burgrave Otto, reduced to that of a gobetween. If the Babonen family did indeed hold the position of monastic advocate, it seems possible that the diminution of Otto's role might have been aimed at staving off any attempt on the part of his successors to claim additional rights in respect of the monastery on the basis of ius fundationis. The importance of the question of the circumstances surrounding the foundation of St James with regard to the autonomy of the monastery is again apparent in the other major historical work produced at the Regensburg Schottenklöster, namely the above-mentioned 13th-century Libellus. Here also Regensburg citizens are attributed a role in the acquisition of the site for the new monastery, but it is assuredly stated that the purchase price and cost of construction were paid for entirely by donations collected on a fund-raising trip back to Ireland. ${ }^{77}$ While monies were raised on such missions to Ireland in the 12th century, none of the recorded journeys predates the foundation of St James. Considering it is in clear contradiction of the 1112 charter, the Libellus spin on events can again be seen as an attempt to assert the independence of the Regensburg monastery, making it appear even more Irish and detached than it actually was. The contrast with the general thrust of the Libellus, which sought to integrate the Irish monastery into the historical narrative of the town, is striking.

\section{Conclusion}

The Schottenklöster story was marked by the constant need to strike a balance between independence and integration, and texts written in the monasteries provide ample evidence of this interplay. The monasteries needed autonomy in order to preserve the essential Irish identity of their enclave, but this could only be achieved by way of integration into the local legal and political 
framework. The black-and-white vision of an independent Irish plantation offered by the author of the Vita Mariani disguises this reality. More representative of the Irish monks' extensive interactions with the world outside the enclave are texts such as the recently-discovered 12th-century Boole Library litany, a text of Schottenklöster provenance which seeks the intercession of a series of both Irish and Regensburg/Bavarian saints, and the annals of the Viennese Schottenklöster, in which the affairs of Babenberg Austria and of Ireland are interspersed. ${ }^{78}$

The notion of the monks of the Schottenklöster as Scotiperegrini fostered by the authors of the historical and hagiographical texts written at the Regensburg Schottenklöster served, on the one hand, to differentiate or "other" the Irish monks, but, through the invocation of the legacy of the Irish missionary saints of the early medieval period and the invention of new legendary material, the existence of Irish monasteries on the Continent was also justified and normalized. The reciprocal relationship between the ideal vision of an enclave and a more pragmatic reality and the role of texts between the two has been a core interest of the Enclaves of Learning, Religion, Ideology and Practice working group, as is reflected in a number of the contributions to this section.

\section{Bibliography}

\section{Primary Sources}

Annales Austriae, ed. Wilhelm Wattenbach, Monumenta Germaniae Historica, Scriptores (MGH SS) 9 (Hannover, 1851), pp. 479-843.

Johannes Aventinus, Herkommen der Stadt Regensburg, in Johannes Turmair's, genannt Aventinus sämmtliche Werke, 1, ed. Matthias Lexer (Munich, 1881), pp. 255-97.

Franz Josef Bendel, ed., Urkundenbuch der Benediktiner-Abtei St. Stephan in Würzburg, 1 (Leipzig, 1912).

Ludwig Bieler, Four Latin Lives of St. Patrick: Colgan's Vita Secunda, Quarta, Tertia, and Quinta, Scriptores Latini Hiberniae 8 (Dublin, 1971).

Albert Brackmann, ed., Germania Pontificia, 1, parts 1 \& 2, Regesta pontificum Romanorum 1.1.2 \& 1.2.2 (Berlin, 1910-1911).

78 Cork, University College, Boole Library, U.331; Ó Riain-Raedel and Ó Riain, "Irish Saints". Regarding the Schottenklöster annals and their place within the labyrinthine manuscript tradition of the high and late medieval Austrian annals, see Annales Austriae, ed. Wattenbach, pp. 604-26; Klebel, "Fassungen und Handschriften", passim; Lhotsky, Quellenkunde, 191-92; Schmale, "Österreichische Annalistik", 181-85; Ó Riain-Raedel “Irish Annals", 127-36. 
Pádraig Breatnach, Die Regensburger Schottenlegende-Libellus de fundacione ecclesie ConsecratiPetri:Untersuchung und Textausgabe, Münchner Beiträge zur Mediävistik und Renaissance-Forschung 27 (Munich, 1977).

Antonius García y García, ed., Constitutiones concilii quarti Lateranensis una cum commentariis glossatorum, Monumenta iuris canonici, series A, 2 (Vatican City, 1981).

Dietrich von Gladiss and Alfred Gawlik, eds., Die Urkunden Heinrichs IV. (MGH, DD H IV). Monumenta Germaniae Historica, Diplomatum regum et imperatorum Germaniae, 6 (Berlin, Weimar, Hannover, 1941-78).

Friedrich Hausmann, ed., Die Urkunden Konrads III. und seines Sohnes Heinrich (MGH, DD K III). Monumenta Germaniae Historica, Diplomatum regum et imperatorum Germaniae, 9 (Vienna, 1969).

Karin Schneider, Die deutschen Handschriften der Bayerischen Staatsbibliothek München: Die mittelalterlichen Handschriften aus Cgm 888-40oo, Catalogus codicum manu scriptorum Bibliothecae Monacensis V/6 (Wiesbaden, 1991).

Ernest Hauswirth, ed., Urkunden der Benediktiner-Abtei Unserer Lieben Frau zu den Schotten in Wien vom Jahre 1158 bis 1418, Fontes Rerum Austriacarum 2.18 (Vienna, 1859).

Dagmar Ó Riain-Raedel, "Das Nekrolog der irischen Schottenklöster: Edition der Handschrift Vat. lat. 10100 mit einer Untersuchung der hagiographischen und liturgischen Handschriften der Schottenklöster", Beiträge zur Geschichte des Bistums Regensburg 26 (1992), pp. 1-119.

Dagmar Ó Riain-Raedel and Pádraig Ó Riain, "Irish Saints in a Regensburg litany”, in Clerics, Kings and Vikings: Essays on Medieval Ireland in Honour of Donnchadh Ó Corráin, eds. Emer Purcell et al. (Dublin, 2015), pp. 55-66.

Otto of Freising, Chronica sive Historia de duabus civitatibus, ed. Adolf Hofmeister, Monumenta Germaniae Historica, Scriptores rerum Germanicarum (MGH SS rer. Germ.) 45 (Hannover, 1912), pp. 1-457.

Otto of Freising, Gesta Friderici I. imperatoris, ed. Georg Waitz, Monumenta Germaniae Historica, Scriptores rerum Germanicarum (MGH SS rer. Germ.) 46 (Hannover, 1912), pp. 1-161.

Johannes Rasch, Stifftung und Prelaten unser lieben Frauen Gottshaus Benedicter-ordens genannt zu den Schotten zu Wienn in Österreich Anno Domini MCLVIII (Vienna, 1586).

Thomas Ried, ed., Codex chronologico-diplomaticus episcopatus Ratisbonensis, 1 (Regensburg, 1816).

Vita Albarti archiepiscopi Casellensis, ed. Wilhelm Levison, Monumenta Germaniae Historica, Scriptores rerum Merovingicarum (MGH SS rer. Merov.) 6 (Hannover, 1913), pp. 21-23.

Vita Erhardi episcopi Bavaraci auctore Paulo, ed. Wilhelm Levison, Monumenta Germaniae Historica, Scriptores rerum Merovingicarum (MGH SS rer. Merov.) 6 (Hannover, 1913), pp. 8-21. 
Matthias Thiel and Alfred Gawlik, eds., Die Urkunden Heinrichs V. und der Königin Mathilde (MGH, DD H V). Monumenta Germaniae Historica, Diplomatum regum et imperatorum Germaniae, 7. (not yet printed, available online at http://www.mgh .de/ddhv/toc.htm).

Stefan Weber, Iren auf dem Kontinent: Das Leben des Marianus Scottus von Regensburg und die Anfänge der irischen "Schottenklöster" (Heidelberg, 2010).

\section{Secondary Literature}

Debra J. Birch, Pilgrimage to Rome in the Middle Ages: Continuity and Change, Studies in the History of Medieval Religion 13 (Woodbridge, 1998).

Dauvit Broun, The Irish Identity of the Kingdom of the Scots in the Twelfth and Thirteenth Centuries, Studies in Celtic History 18 (Woodbridge, 1999).

Peter Csendes, "Die Aufenthaltsorte der Babenberger in Niederösterreich und Steiermark", Jahrbuch des Vereins für Geschichte der Stadt Wien 34 (1978), 24-32.

Peter Csendes, "Regensburg und Wien-Babenbergerresidenzen des 12. Jahrhunderts", Jahrbuch des Vereins für Geschichte der Stadt Wien 47/48 (1991/1992), 163-71.

James Coombes, "The Benedictine Priory of Ross", Journal of the Cork Historical and Archaeological Society 73 (1968), 152-60.

Giles Constable, Monastic Tithes from their Origins to the Twelfth Century (Cambridge, 1964).

Florent Cygler, Das Generalkapitel im hohen Mittelalter: Cisterzienser, Prämonstratenser, Kartäuser und Cluniazenser, Vita regularis 12 (Münster, 2002).

Herwig Ebner, "Die Frühgeschichte Wiens", in Frühgeschichte der europäischen Stadt: Vorraussetzungen und Grundlagen, eds. Hansjürgen Brackmann and Joachim Herrmann, Schriften zur Ur- und Frühgeschichte 44 (Berlin, 1991), 6o-67.

Helmut Flachenecker, Schottenklöster: Irische Benediktinerkonvente im hochmittelalterlichen Deutschland (Paderborn, 1995).

Helmut Flachenecker, "Hagiographische Werke als Kommunikationshilfen für Fremde”, in Hagiographie im Kontext: Wirkungsweisen und Möglichkeiten historischer Auswertung, eds. Dieter R. Bauer and Klaus Herbers (Stuttgart, 2000), 96-116.

Bettina Gröber, "Res factae versus res fictae: Konrad von Megenberg und seine überlieferungsgeschichtliche Relevanz für die Lektüre der Regensburger Schottenlegende", in Konrad von Megenberg (1309-1374): ein spätmittelalterlicher "Enzyklopädist" im europäischen Kontext, ed. Edith Feistner, Jahrbuch der Oswald von WolkensteinGesellschaft 18 (Wiesbaden, 2011), 359-69.

Kassius Hallinger, "Zur geistigen Welt der Anfänge Klunys", Deutsches Archiv für Erforschung des Mittelalters 10 (1954), 417-45. 
Karl Halm et al., eds., Catalogus codicum latinorum bibliothecae regiae Monacensis, 4/2 (Munich, 1876).

Ludwig Hammermayer, "Die irischen Benediktiner-'Schottenklöster' in Deutschland und ihr institutioneller Zusammenschluß vom 12.-16. Jahrhundert”, Studien und Mitteilungen zur Geschichte des Benediktinerordens und seiner Zweige 87 (1976), 249-339.

John Hennig, "St Albert, Patron of Cashel: a Study in the History of Diocesan Episcopacy in Ireland", Mediaeval Studies 7 (1945), 21-39.

Arno Herzig, "Die Deutschordenskommende Würzburg im Mittelalter (1219-1549): Ihre Stellung als bischöfliche 'Hauskommende' und Komturspfründe", Mainfränkisches Jahrbuch für Geschichte und Kunst 18 (1966), 1-120.

Hans Hirsch, Die Klosterimmunität seit dem Investiturstreit: Untersuchungen zur Verfassungsgeschichte des deutschen Reiches und der deutschen Kirche (Weimar, 1913).

Werner Goez, "Imperator advocatus Romanae ecclesiae", in Aus Kirche und Reich: Studien zu Theologie, Politik und Recht im Mittelalter, ed. Hubert Mordek (Sigmaringen, 1983), 315-28.

Ernst Klebel, "Die Fassungen und Handschriften der österreichischen Annalistik", Jahrbuch für Landeskunde von Niederösterreich N.S. 21 (1928), 43-185.

Elisabeth Klemm, Die romanischen Handschriften der Bayerischen Staatsbibliothek. Teil 1: Die Bistümer Regensburg, Passau und Salzburg (text vol.) (Wiesbaden, 1980).

Margrit Koch, Sankt Fridolin und sein Biograph Balther: Irische Heilige in der literarischen Darstellung des Mittelalters (Zürich, 1959).

Gisela Koschwitz, "Der heilige Bischof Erhard von Regensburg: Legende-KultIkonographie", Studien und Mitteilungen zur Geschichte des Benediktinerordens und seiner Zweige 86 (1975), 481-644.

Hermann Krabbo, "Die Versuche der Babenberger zur Gründung einer Landeskirche in Österreich”, Archiv für österreichische Geschichte 93 (1905), 1-41.

Andreas Kraus, Das Bild Regensburgs in der deutschen Geschichtsschreibung des Mittelalters, Regensburg historische Forschungen 3 (Kallmünz, 1972), 86-102.

Karl Lechner, DieBabenberger: Markgrafen und Herzöge von Österreich 976-1246 (Vienna, 1976).

Alphons Lhotsky, Quellenkunde zur mittelalterlichen Geschichte Österreichs, Mitteilungen des Instituts für Österreichische Geschichtsforschung, Ergänzungsband 19 (Graz, 1963).

Christina Lutter, "Geistliche Gemeinschaften in der Welt", in Innovationen durch Deuten und Gestalten: Klöster im Mittelalter zwischen Jenseits und Welt, eds. Gert Melville et al. (Regensburg, 2014), 145-160.

Paul Mai, "Der heilige Bischof Erhard”, in Bavaria Sancta: Zeugen christlichen Glaubens in Bayern, 2, ed. Georg Schwaiger (Regensburg, 1971), 30-51. 
Gert Melville, Die Welt der mittelalterlichen Klöster: Geschichte und Lebensform (Munich, 2012), 303-07.

John C Moore, Pope Innocent III (116o/1-1216): To Root Up and to Plant (Leiden, 2003).

Otto Gerhard Oexle, "Memoria als Kultur", in, Memoria als Kultur, ed. Otto Gerhard Oexle, Veröffentlichungen des Max-Planck-Instituts für Geschichte 121 (Göttingen, 1995), 9-78.

Alexander O'Hara, “Constructing a Saint: the Legend of St Sunniva in Twelfth-Century Norway", Viking and Medieval Scandinavia 5 (2009), 105-21.

Dagmar Ó Riain-Raedel, "Twelfth- and Thirteenth-Century Irish Annals in Vienna", Peritia:Journal of the Irish Medieval Academy 2 (1983), 127-36.

Dagmar Ó Riain-Raedel, "Irish Kings and Bishops in the Memoria of the German Schottenklöster", in Irland und Europa: die Kirche im Frühmittelalter, eds. Próinséas Ní Chatháin and Michael Richter (Stuttgart, 1984).

Dagmar Ó Riain-Raedel, "Patrician Documents in Medieval Germany”, Zeitschrift für celtische Philologie 49-50 (1997/1998), 712-24.

Dagmar Ó Riain-Raedel, "Irish Benedictine Monasteries on the Continent", in The Irish Benedictines, eds. Martin Browne and Colmán Ó Clabaigh (Dublin, 2005), 25-63.

Dagmar Ó Riain-Raedel, "Cashel and Germany: the Documentary Evidence”, in Ireland and Europe in the Twelfth Century: Reform and Renewal, eds. Damian Bracken and Dagmar Ó Riain-Raedel (Dublin, 2006), 176-217.

Dagmar Ó Riain-Raedel, "Vita sancti Coemgeni: an Edition of the Earliest Manuscript Version", in Glendalough: City of God, eds. Charles Doherty, Linda Doran and Mary Kelly (Dublin, 2011), 145-64.

Diarmuid Ó Riain, "New Light on the History of St Mary's Priory, Rosscarbery", Journal of the Cork Historical and Archaeological Society 113 (2008), 56-68.

Diarmuid Ó Riain, "Schottenklöster: the Early History and Architecture of the Irish Benedictine Monasteries in Medieval Germany" (unpublished $\mathrm{PhD}$ thesis, University College Dublin, 2008).

Diarmuid Ó Riain, "An Irish Jerusalem in Franconia: the Abbey of the Holy Cross and Holy Sepulchre at Eichstätt", Proceedings of the Royal Irish Academy (Section C) 112 (2012), 219-70.

Diarmuid Ó Riain, "The Magnum Legendarium Austriacum: a New Investigation of one of Medieval Europe's Richest Hagiographical Collections", Analecta Bollandiana 133 (2015), 87-165.

Diarmuid Ó Riain, "The Schottenklöster and the Legacy of the Irish sancti peregrini", in "A Fantastic and Abstruse Latinity": Hiberno-Continental Cultural and Literary Interactions in the Middle Ages, eds. Wolfram Keller and Dagmar Schlüter (Münster, in press).

Friedrich Oswald, "Der Westbau der ehemaligen Schottenkirche in Würzburg", Mainfränkisches Jahrbuch für Geschichte und Kunst 10 (1958), 20-39, at 35-36. 
Gerhard Pfeiffer, "Die Anfänge der Egidienkirche zu Nürnberg: Ein Beitrag zur ältesten Stadtgeschichte", Mitteilungen des Vereins für Geschichte der Stadt Nürnberg 37 (1940), 255-308.

Albert Poncelet, “De Magno Legendario Austriaco”, Analecta Bollandiana 17 (1898), 24-96, 123-216.

Michael Richter, "Die Iren-Identität und Struktur einer gens am europäischen Rand”, in Völker, Reiche und Namen im frühen Mittelalter, eds. Matthias Becher and Stefanie Dick, Mittelalterstudien 22 (Munich, 2010), 245-54.

Jens Röhrkasten, "Regionalism and Locality as Factors in theStudy of Religious Orders", in MittelalterlicheOrdenundKlösterim Vergleich:MethodischeAnsätze undPerspektiven, eds. Gert Melville and Anne Müller, Vita regularis 34 (Berlin, 2007), 243-68.

Franz-Josef Schmale, "Die österreichische Annalistik im 12. Jahrhundert", Deutsches Archiv zur Erforschung des Mittelalters 31 (1975), 144-203.

Karl Schmid and Joachim Wollasch, "Die Gemeinschaft der Lebenden und Verstorbenen in Zeugnissen des Mittelalters", Frühmittelalterliche Studien 1 (1967), 365-405.

Karin Schneider, Die deutschen Handschriften der Bayerischen Staatsbibliothek München:Die mittelalterlichen Handschriften aus Cgm 888-40oo, Catalogus codicum manu scriptorum Bibliothecae Monacensis V/6 (Wiesbaden, 1991).

Ernst Schubert, "Fremde im mittelalterlichen Deutschland", IMIS-Beiträge 7 (1998), 7-33.

Ulrich Schuldi, "Advocatus sanctae Romanae ecclesiae und specialis filius beati Petri: Der römische Kaiser aus päpstlicher Sicht", in Staufisches Kaisertum im 12. Jahrhundert: Konzepte-Netzwerke-Politische Praxis, eds. Stefan Burkhardt et al. (Regensburg, 2010), 41-73.

Frank Shaw, Karl der Große und die schottischen Heiligen, Deutsche Texte des Mittelalters 71 (Berlin, 1981).

Wilhelm Störmer, "Babonen", in Lexikon des Mittelalters 1 (Munich, 1977), cols. 1322-23.

Brigitte Szabó-Bechstein, “Libertas ecclesiae’ vom 12. bis zur Mitte des 13. Jahrhunderts. Verbreitung und Wandel des Begriffs seit seiner Prägung durch Gregor VII", in Die abendländische Freiheit vom 10. zum 14. Jahrhundert: Die Wirkungszusammenhang von Idee und Wirklichkeit im europäischen Vergleich, ed.Johannes Fried (Sigmaringen, 1991), 147-75.

Hans Thieme, "Fremdenrecht", in Handwörterbuch zur deutschen Rechtsgeschichte, ed. Adalbert Erler and Ekkehard Kaufmann, 1 (Berlin, 1971), 1270-72.

Steven Vanderputten, "Introduction", in id., Reform, Conflict, and the Shaping of Corporate Identities: Collected Studies on Benedictine monasticism, 1050-1150, Vita regularis 12 (Vienna, 2013), IX-XXVIII.

Stefan Weber, “Die Konstruktion eines fabulösen 'irischen' Heiligenlebens? Der heilige Albert, Regensburg und die Iren”, in Irische Mönche in Süddeutschland: Literarisches 
und kulturelles Wirken der Iren im Mittelalter, eds. Dorothea Walz and Jakobus Kaffanke (Heidelberg, 2009), 229-304.

Ernst Werner, Pauperes Christi: Studien zu sozial-religiösen Bewegungen im Zeitalter des Reformpapsttums (Leipzig, 1956).

Michael Wieland, "Das Schottenkloster zu St. Jakob in Würzburg”, Archiv des Historischen Vereins von Unterfranken und Aschaffenburg 16 (1863), 1-183.

Peter Wolf, Bilder und Vorstellungen vom Mittelalter: Regensburger Stadtchroniken der frühen Neuzeit, Frühe Neuzeit 49 (Tübingen, 1999).

Joachim Wollasch, "Spuren Hirsauer Verbrüderungen”, in Hirsau St. Peter und Paul 1091-1991, vol. 2.: Geschichte, Lebens- und Verfassungsformen eines Reformklosters, ed. Klaus Schreiner, Forschungen und Berichte der Archäologie des Mittelalters in Baden-Württemberg 10, 2 (Stuttgart, 1991), 173-93. Repr. in Joachim Wollasch, Wege zur Erforschung der Erinnerungskultur: Ausgewählte Aufsätze (Münster, 2011), 455-98.

Alex Woolf, From Pictland to Alba 789-1070, The New Edinburgh History of Scotland, vol. 2 (Edinburgh, 2007).

Wolfram Ziegler, König Konrad III. (1138-1152): Hof, Urkunden und Politik, Forschungen zur Kaiser- und Papstgeschichte des Mittelalters 26 (Vienna, 2008). 